\title{
The genetically engineered drug rhCNB induces apoptosis via a mitochondrial route in tumor cells
}

\author{
Yang Yang ${ }^{1, *}$, Huan Yang ${ }^{1, *}$, Jinju Yang ${ }^{1}$, Li Li ${ }^{1}$, Benqiong Xiang ${ }^{1}$ and Qun Wei ${ }^{1}$ \\ ${ }^{1}$ Department of Biochemistry and Molecular Biology, Beijing Normal University, Beijing Key Laboratory, Beijing 100875, \\ People's Republic of China \\ "These authors have contributed equally to this work \\ Correspondence to: Qun Wei, email: weiq@bnu.edu.cn \\ Benqiong Xiang, email: Xiangbq@bnu.edu.cn
}

Keywords: rhCNB, mitochondrial apoptosis, BCl-2 family, tumor targeting, anti-tumor drug

Received: November 30, $2016 \quad$ Accepted: June 27, $2017 \quad$ Published: July 22, 2017

Copyright: Yang et al. This is an open-access article distributed under the terms of the Creative Commons Attribution License 3.0 (CC BY 3.0), which permits unrestricted use, distribution, and reproduction in any medium, provided the original author and source are credited.

\section{ABSTRACT}

The calcineurin B subunit (CNB) has antitumor activity. We showed previously that recombinant human CNB (rhCNB) also had strong anti-tumor activity in vivo, and was thus a promising candidate anti-tumor drug. It appeared to kill tumor cells via immunomodulation. Here, we show that rhCNB inhibits the proliferation of human hepatoma HepG-2 cells, resulting in their apoptosis. Exogenous CNB was found to localize to mitochondria in tumor cells and activate the mitochondrial apoptosis pathway, as indicated by a decrease of mitochondrial transmembrane potential, release of cytochrome $C$ and activation of caspase-9, which then activates caspase-3. At the same time $\mathrm{Bcl}-2$ \& Bcl-xL expression decreased, Bim expression increased, and Bax was activated. Interaction between rhCNB and Bcl-xL was detected, which may inhibit the function of $\mathrm{BCl}-\mathrm{xL}$. Long-term tumor targeting was also observed in nude mice. These data deepened our understanding of the anti-tumor mechanism of rhCNB and provided guidance for its drug development.

\section{INTRODUCTION}

Calcineurin $(\mathrm{CN})$ is a calcium- and calmodulindependent serine/threonine protein phosphatase $[1,2]$, whose function and structure have been widely studied. It plays a central role in activating immune cells and is the target of the much-used immunosuppressive agents cyclosporin A (CsA) and tacrolimus (FK506) [3, 4]. It is also involved in transcriptional and post-transcriptional regulation of apoptosis $[5,6]$. $\mathrm{CN}$ is a heterodimer composed of A and B subunits. The A subunit $(\mathrm{CnA})$ is a $61 \mathrm{kD}$ catalytic subunit, with three regulatory domains: a CNB-binding domain (BBH), a CaM-binding domain (CBD) and an auto-inhibitory domain (AID). The B subunit $(\mathrm{CNB})$ is a $19 \mathrm{KD}$ regulatory subunit with four $\mathrm{Ca}^{2+}$ binding sites [7-9]. These regions and sites are essential for $\mathrm{Ca}^{2+}$ regulation of $\mathrm{CN}$ activity.

The basic role of CNB is to regulate the phosphatase activity of $\mathrm{CN}$ and stabilize its structure, allowing it to participate in cell metabolism and signal pathway regulation. However, CNB also has other, non-regulatory, roles. It is involved in apoptosis and the proteasome pathway by interacting with heat shock protein 60 , tubulin, pro-caspase 3 and other proteins [10-11]. CNB-deficient mice have a high risk of squamous cell carcinoma, suggesting that $\mathrm{CNB}$ has anti-tumor activity [6]. We have shown that recombinant human CNB (rhCNB) has a strong anti-tumor effect in a variety of tumor models. It significantly extended the survival of mice bearing $\mathrm{H}_{22}$ hepatoma ascites and S180 sarcoma tumors [12], and it had a pronounced antitumor effect on the B16 lung metastasis model in C57 mice [13]. These results indicate that rhCNB holds promise as an anti-tumor drug, and rhCNB has been developed as a genetically-engineered drug, patented in China and the US $[14,15]$. In terms of its anti-tumor mechanism, studies have shown that it activates the immune system by inducing the maturation and activation of dendritic cells and enhancing their antigenpresenting activity [16]; it also promotes the proliferation of peritoneal macrophages and stimulates their phagocytic 
activity synergistically with IFN- $\gamma$ [13]; furthermore it interacts with integrin $\alpha \mathrm{M}$ and increases TNF-related apoptosis-inducing ligand (TRAIL) expression in macrophages, thereby inducing tumor cell apoptosis $[17$, 18]. Studies have also shown that overexpression of CNB can significantly increase TNF- $\alpha / \mathrm{CHX}$-induced apoptosis, which may be achieved by affecting the function of mitochondria [19], and exogenous CNB rapidly enters cells through TLR4 receptors and induces the secretion of cytokines, but have certain cytotoxicity in some TLR4rich tumor cells [20]. Interestingly, we observed that exogenous CNB rapidly enters tumor cells and becomes located in mitochondria. This observation led us to ask whether rhCNB can induce apoptosis of tumor cells directly, aside from any action on the immune system, and if so, what mechanism is involved.

There are two main pathways of apoptosis. The death receptor signaling pathway, also known as the extrinsic pathway, is activated by binding of specific ligands to death receptors on the cell membrane; this recruits the Fas-related death domain (FADD) and caspase- 8 to form the death-inducing signaling complex (DISC), which then leads to activation of caspases and induces apoptosis $[21,22]$. The mitochondrial apoptotic pathway, the so-called intrinsic pathway, is often initiated by the activation of pro-apoptotic members (eg Bax, Bak) on the OMM to form channels, allowing the escape of mitochondrial contents, and finally apoptosis is induced by a cascade of reactions [23-25]. The anti-apoptotic members (eg Bcl-2, Bcl-xL, Bcl-W) are generally sequestered within the OMM to inhibit activation of the pro-apoptotic ones [26, 27], while the BH3-only proteins (eg Bid, Bim, Bad) either interact with the anti-apoptotic proteins to inhibit their function, or activate pro-apoptotic proteins directly [28-32]. Thus the balance of Bcl-2 family members can decide cell fate.

In order to test the hypothesis that rhCNB can induce apoptosis of tumor cells directly, we treated HepG-2 cells with rhCNB and found that it inhibited their proliferation and activated mitochondrial apoptosis pathway. We investigated for the first time the cytotoxicity of rhCNB on hepatoma cells and the important inhibitory effect on $\mathrm{Bcl}-\mathrm{xL}$ activity in this process, which further elucidated the anti-tumor mechanism of rhCNB and promoted the drug development process of rhCNB. Meanwhile, we also found that rhCNB has the property of tumor targeting in vivo, providing a new perspective for further research.

\section{RESULTS}

\section{Exogenous CNB inhibits the proliferation of HepG-2 cells by apoptosis}

To examine the antiproliferative activity of $\mathrm{rhCNB}$, HepG-2 cells were exposed to various concentrations of rhCNB for $48 \mathrm{~h}$, after which the extent of cell death was monitored by CCK8 assay. The cytotoxicity of rhCNB for normal human LO2 liver cells was also evaluated. The relative viability for HepG-2 cells was $81.67 \pm 3.48 \%$ at $5 \mu \mathrm{M}$ and decreased to $34.23 \pm 3.44 \%$ at $35 \mu \mathrm{M}$ (Figure 1A), while little to no cytotoxicity was observed for LO2 cells (Figure 1B), indicating that rhCNB has low general toxicity, and this is not due to absence of incorporation as rhCNB can enter both HepG-2 and LO2 cells (Supplementary Figure 1). A dose-dependent increase in the percentage of apoptotic HepG-2 cells from $7.40 \pm$ $1.35 \%$ to $62.86 \pm 4.72 \%$ was observed after treatment with $5-35 \mu \mathrm{M}$ of rhCNB (Figure 1C) determined by Annexin $\mathrm{V}$ binding, suggesting that most of the antiproliferative activity of rhCNB is mediated by apoptosis. Meanwhile, activation of caspase-3, an important physiological and biochemical marker of apoptosis was detected. RhCNB increased the level of cleaved caspase- 3 in a dosedependent manner (Figure 1E) and resulted in a significant increase of caspase- 3 activity (Figure 1D). Furthermore, morphological changes induced by rhCNB were observed in DsRed2/HistoneH2B-EGFP dual-labeled HepG-2 cells (Figure 1F): after incubation with $35 \mu \mathrm{M}$ rhCNB for 48 $\mathrm{h}$, the nuclei of HepG-2 cells (green) were disrupted and overlapped with the cytoplasm (red) to produce a bright yellow color, indicating that apoptosis had occurred.

\section{Exogenous CNB enters tumor cells and localizes in mitochondria}

It has been shown that rhCNB rapidly enters tumor cells [20]. To see if it becomes associated with mitochondria we incubated Mito-DsRed-transfected sk-hep-1 cells with exogenous CNB-GFP. As shown in Figure 2A, CNB-GFP co-localized with Mito-DsRed, indicating that the exogenous rhCNB became localized to mitochondria. To confirm this, rhCNB was incubated with sk-hep-1 cells for 20, 40 or $60 \mathrm{~min}$, and mitochondrial rhCNB content was measured. RhCNB became associated with the mitochondria; its level increased with time (Figure 2B) and remained co- localized with mitochondria for 24 and $48 \mathrm{~h}$ (Figure 2C), suggesting that it may enter the inner space of mitochondria. We therefore digested the outer mitochondrial membrane protein with protease $\mathrm{K}$. As shown in the Figure 2D, rhCNB was indeed still found in the mitochondria (upper panel) while the mitochondrial outer membrane protein Bcl-xL had been lost.

\section{Mitochondrial damage and caspase activation are involved in rhCNB-induced apoptosis}

In response to rhCNB treatment, HepG-2 and Skhep-1 cells were found to undergo a dose-dependent increase in mitochondrial depolarization, reflected by a decrease in mitochondrial transmembrane potential (Figure 3A, 3B). HepG-2 cells were the more sensitive of the two cell types: their membrane potential was reduced 
A

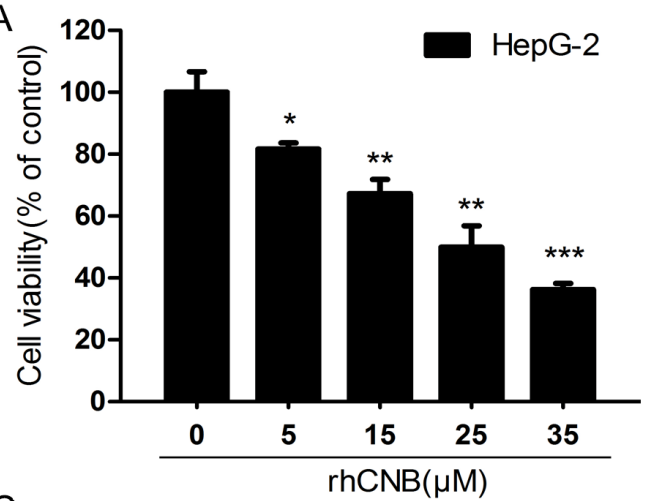

C
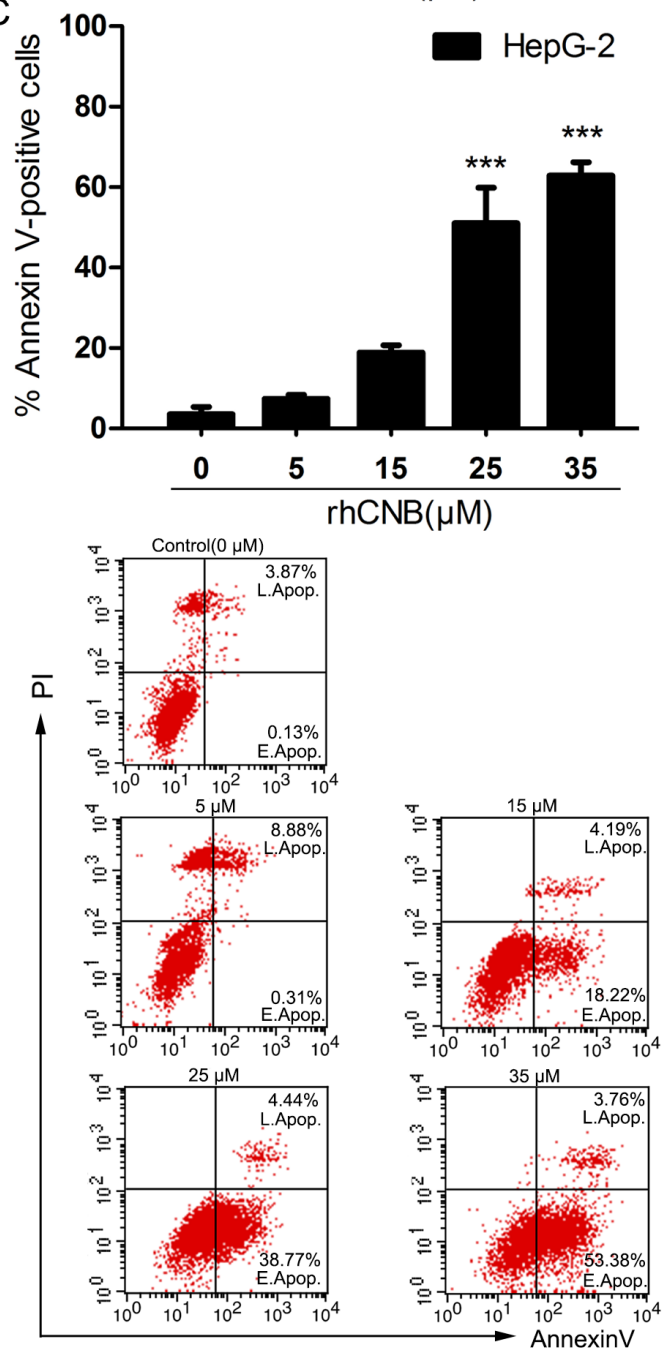

B
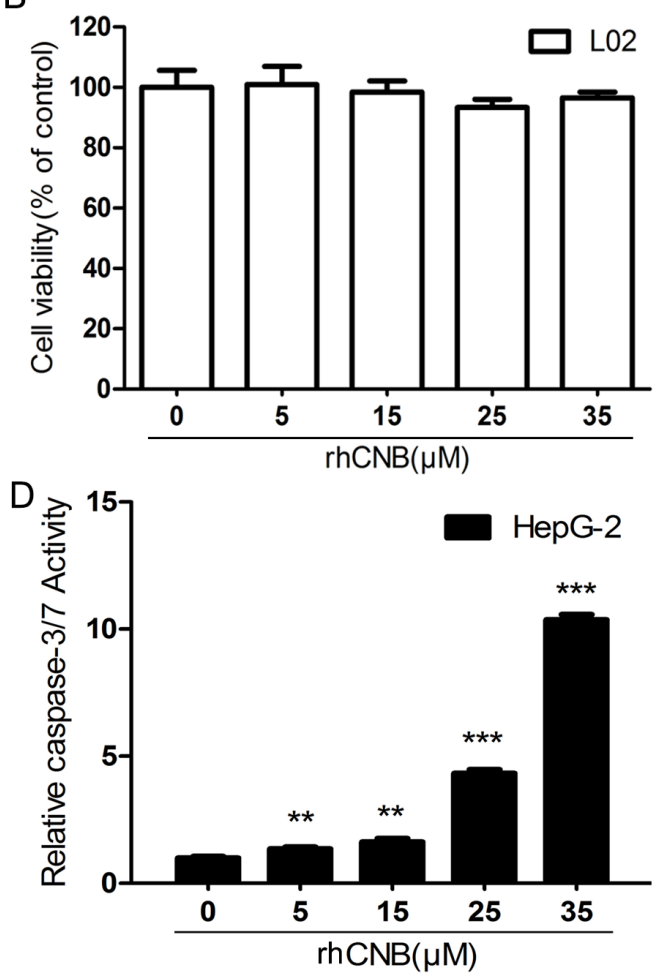

$\mathrm{E}$ HepG-2

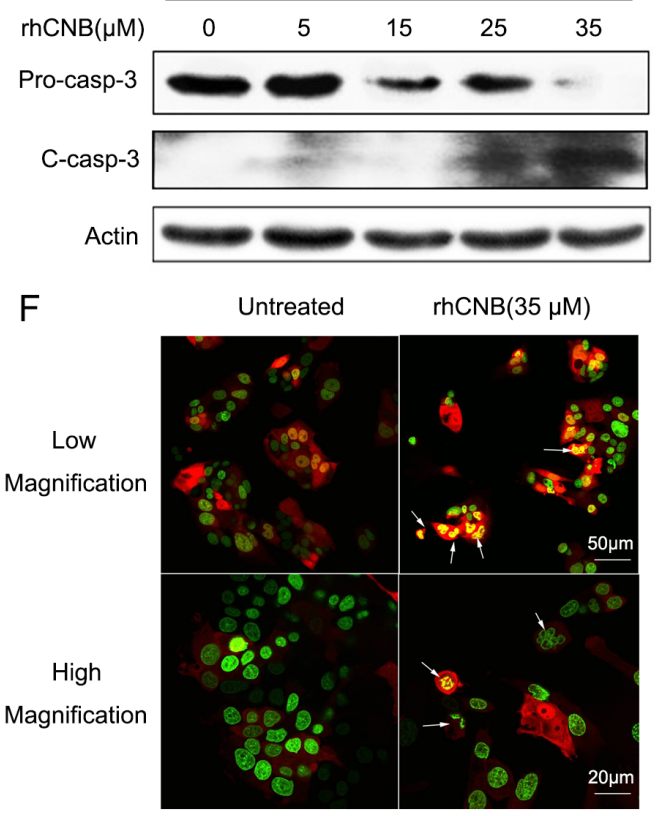

Figure 1: The antiproliferative activity of rhCNB is due to apoptosis. (A, B) Dose-dependent decrease in cell viability. HepG2(A) and $\mathrm{LO} 2$ (B) cells were treated with increasing concentrations of rhCNB $(0-35 \mu \mathrm{M})$ for $48 \mathrm{~h}$. The relative cell viability was shown as mean $\pm \mathrm{SD},{ }^{*} P<0.05 ; * * P<0.01 ; * * * P<0.001$ (compared with control). (C) rhCNB increases apoptosis in a dose-dependent manner. HepG-2 cells were treated with varying concentrations of rhCNB $(0-35 \mu \mathrm{M})$ for $48 \mathrm{~h}$ before stained with annexin $\mathrm{V}$ assay. Detailed apoptosis analyses are shown in the histogram, representing the mean percentages \pm SD of apoptosis in three independent experiments, ${ }^{* * *} P<0.001$ (compared with control). The lower panel shows scatter plots of the percentages of early and late apoptosis in one experiment. (D) Caspase-3/7 activity is increased by rhCNB. Caspase-3/7 catalytic activity was analyzed in HepG-2 cells treated with varying concentrations of rhCNB. Shown are mean $\pm \mathrm{SD}, * * P<0.01 ; * * * P<0.001$ (compared with control). (E) Cleaved caspase-3 levels observed by Western blotting. (F) Condensation of chromatin material and fragmentation of nuclei in apoptotic cells. HepG-2 cells stably transfected with the nuclear marker Histone H2B-EGFP and cytoplasmic marker DsRed2 were treated with $35 \mu \mathrm{M}$ rhCNB for $48 \mathrm{~h}$ and examined with a Zeiss LSM700 confocal laser scanning microscope. 
by $72.6 \%$ when incubated with $35 \mu \mathrm{M}$ rhCNB. This was accompanied by profound mitochondrial damage, reflected in a marked increase in cytosolic cytochrome (Figure $3 \mathrm{C})$. In addition, rhCNB was found to trigger activation of the initiator caspase, caspase-9, as demonstrated by a decrease in the pro-caspase form and the appearance of the corresponding cleaved form. These observations suggest that activation of the mitochondrial pathway is responsible for the induction of apoptosis by rhCNB.

\section{Exogenous CNB modulates the expression and function of Bcl-2 family members}

Members of the Bcl-2 family are thought to regulate mitochondrial outer membrane integrity, thus controlling apoptosis. We therefore investigated whether exogenous CNB influences the expression and function of Bcl-2 family members. It was found that rhCNB dosedependently decreased the protein levels of Bcl-2 and Bcl-xL, both being anti-apoptotic proteins (Figure 4A, 4B). Meanwhile, rhCNB also increased the protein level of Bim, a BH3-only protein (Figure 4A, 4B) that binds to various $\mathrm{Bcl}-2$ anti-apoptotic proteins and inhibits their function [33-34]. There were three spliced forms of Bim (BimEL, BimL, BimS) in HepG-2 cells, but only the first two in SK-hep-1 cells, which is generally the case [35]. Results of real-time quantitative PCR showed consistent trends in mRNA levels (Supplementary Figure 2 ), indicating that the changes in the protein levels may be partly due to effects on gene expression. When the balance of anti- and pro-apoptotic proteins tilts towards the latter, apoptosis is induced. In view of the important role of the multi-domain protein Bax in apoptosis [36], we also examined its activation in HepG-2 and Sk-hep-1
A

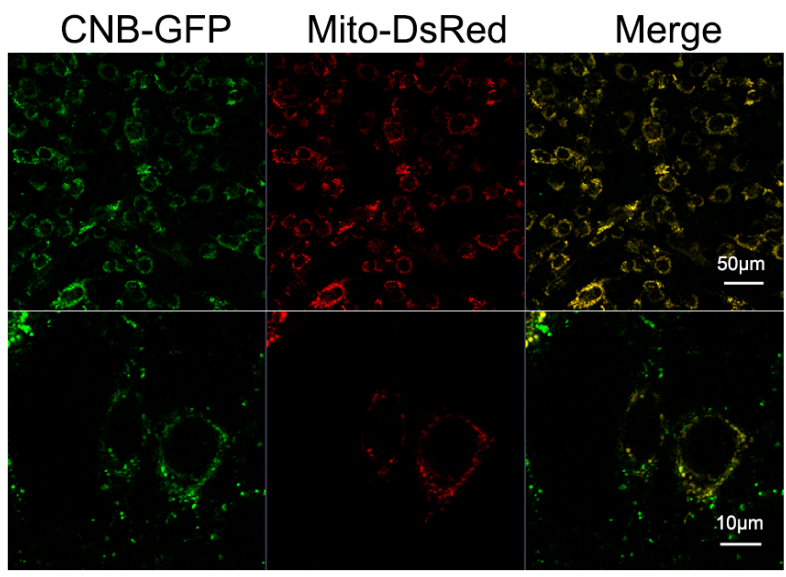

C

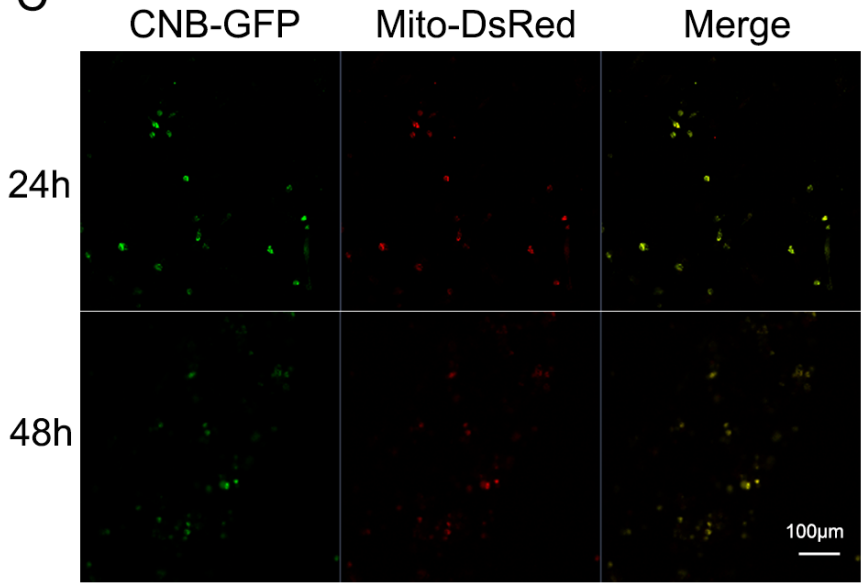

B

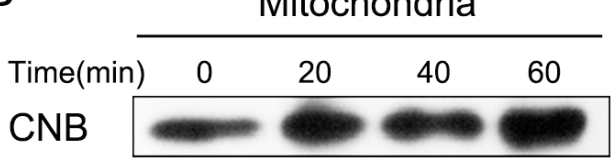

Actin
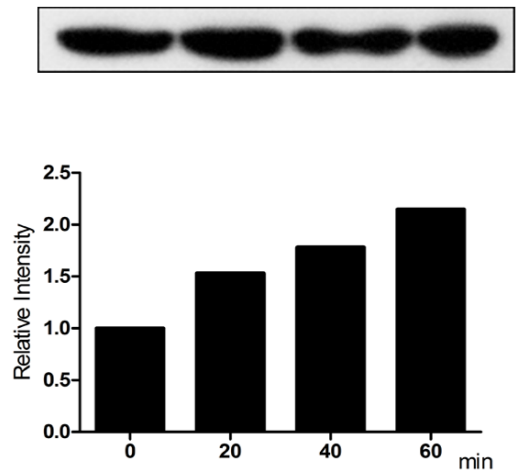

D

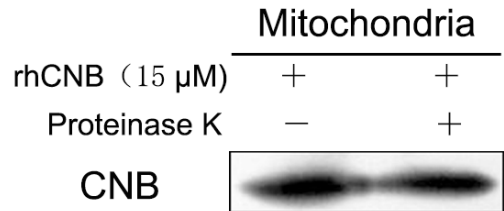

$\mathrm{BCl}-\mathrm{xL}$

VDAC1

Figure 2: Exogenous CNB becomes localized in mitochondria. (A) rhCNB co-localizes with mitochondria. Sk-hep-1 cells were transfected with the mitochondrial marker Mito-DsRed for $48 \mathrm{~h}$ and treated with $5 \mu \mathrm{M} \mathrm{CNB}-\mathrm{GFP}$ for 30 min, then visualized using a

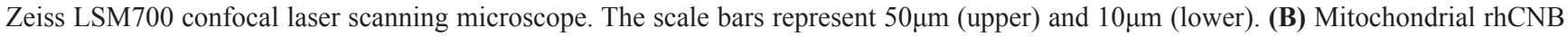
at different times. Sk-hep-1 cells were incubated with $10 \mu \mathrm{M}$ rhCNB for 0, 20, 40, 60 min after which mitochondria were isolated for Western blotting. The graph represents the mean of the densitometric intensities of the visualized bands. (C) The persistence of rhCNB in mitochondria. Sk-hep-1 cells were transfected with the mitochondrial marker Mito-DsRed for $48 \mathrm{~h}$ and treated with $5 \mu \mathrm{M}$ CNB-GFP for $24 \mathrm{~h}$ and $48 \mathrm{~h}$, then visualized using a Zeiss LSM700 confocal laser scanning microscope. The scale bar represents 100 $\mu \mathrm{m}$. (D) rhCNB can enter the inner space of mitochondria. Mitochondria isolated from HepG-2 cells treated with $15 \mu \mathrm{M}$ rhCNB for $6 \mathrm{~h}$ were digested with proteinase $\mathrm{K}$ for $30 \mathrm{~min}$, and the lysates were subjected to western blotting. 
cells and found that rhCNB promoted formation of the active Bax conformation (6A7), with no major change in the level of the protein (Figure 4A). We may therefore suppose that activation of Bax by rhCNB is mediated by down-regulation of Bcl-2 and Bcl-xL and up-regulation of Bim, which further activates the mitochondrial apoptotic pathway.

However, the role of rhCNB localization in the mitochondria remains unclear. Is it possible that it interacts with proteins in the mitochondria, which in turn affect mitochondrial function? This idea led us to test
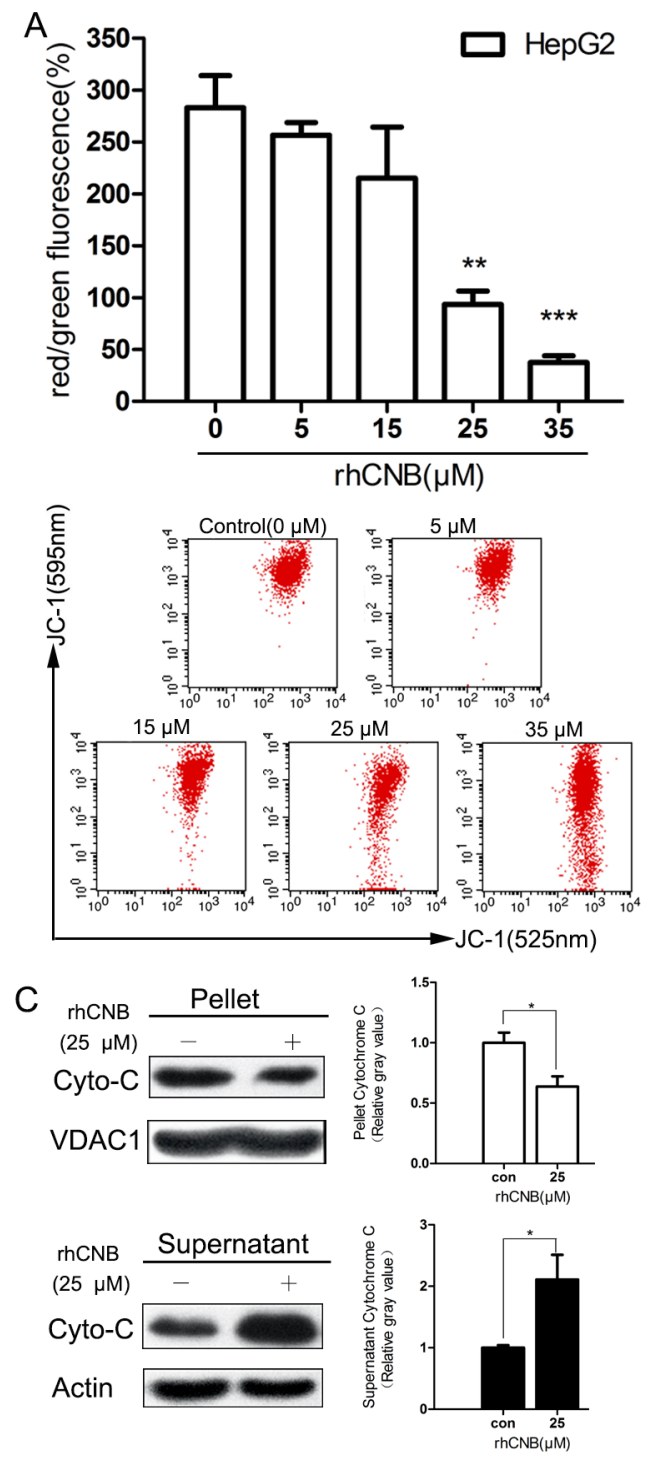

whether rhCNB interacted with Bcl-2 or Bcl-xL, two antiapoptotic Bcl-2 proteins located on the outer membrane of mitochondria. Co-immunoprecipitation experiments showed that rhCNB failed to bind to Bcl-2 (Supplementary Figure 3), but it did bind to Bcl-xL, in vitro as well as in cell-free system (Figure 4C). As Bcl-xL has been reported to inhibit the translocation of pro-apoptotic Bax from the cytoplasm to mitochondria [27], we conjectured that binding of rhCNB to Bcl-xL might disrupt the interaction between Bcl-xL and Bax. As shown in Figure 4D, binding of Bcl-xL to Bax in HepG-2 cells was indeed weakened
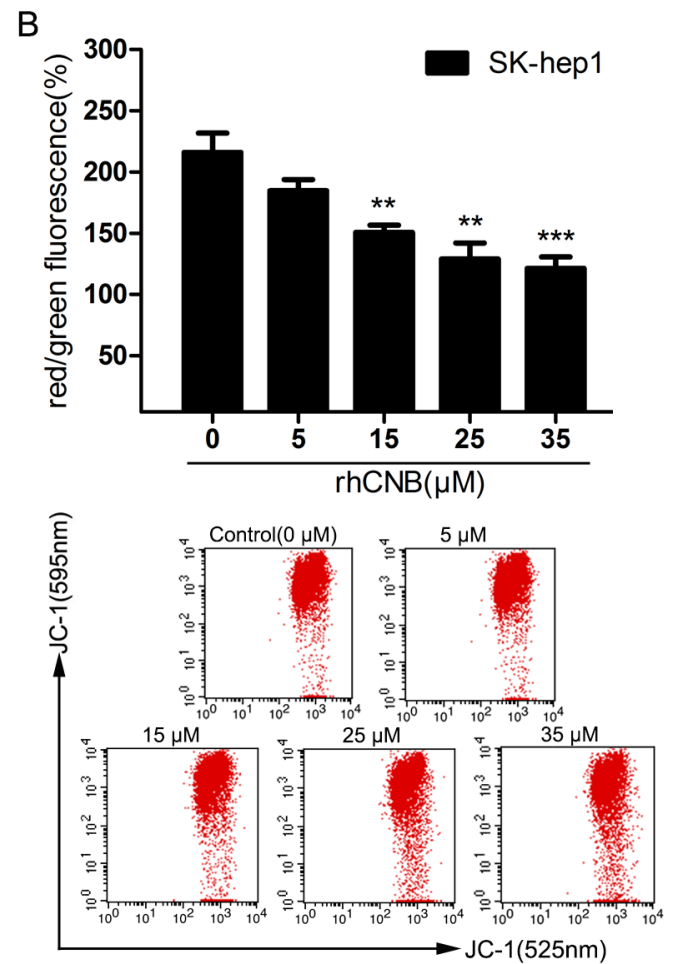

$\mathrm{D}$

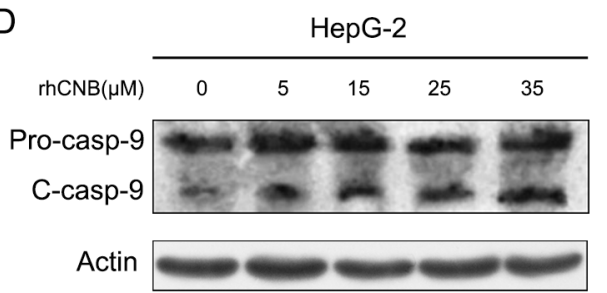

Figure 3: Exogenous CNB damages HepG-2 and Sk-hep-1 mitochondria. HepG-2 cells (A) and SK-hep-1 cells (B) were treated with increasing concentrations of rhCNB $(0-35 \mu \mathrm{M})$ for $24 \mathrm{~h}$. Cells were harvested, stained with JC-1 dye and analyzed by flow cytometer. The mitochondrial membrane potential was represented by the ratio of red to green fluorescence intensity (100\%), where red represents JC-1 aggregates in intact mitochondria and green represents green fluorescing monomers in the cytosol. Bar diagram shows the mean mitochondrial membrane potentials \pm SDs of three independent experiments, $* * P<0.01$; *** $P<0.001$ (compared with control). The lower panel illustrates the loss of red fluorescence with increasing rhCNB in one experiment. (C) rhCNB causes release of cytochrome $\mathrm{C}$ to the cytosol. HepG-2 cells were treated with $25 \mu \mathrm{M}$ rhCNB for $48 \mathrm{~h}$ and cytochrome $\mathrm{C}$ release was assessed by Western blotting of pellet versus supernatant. Bar diagram shows the mean mitochondrial or cytosolic cytochrome $\mathrm{C} \pm \mathrm{SDs}$ of three independent experiments, $* P<0.05$. (D) Cleaved caspase-9 levels observed by Western blotting. 
A

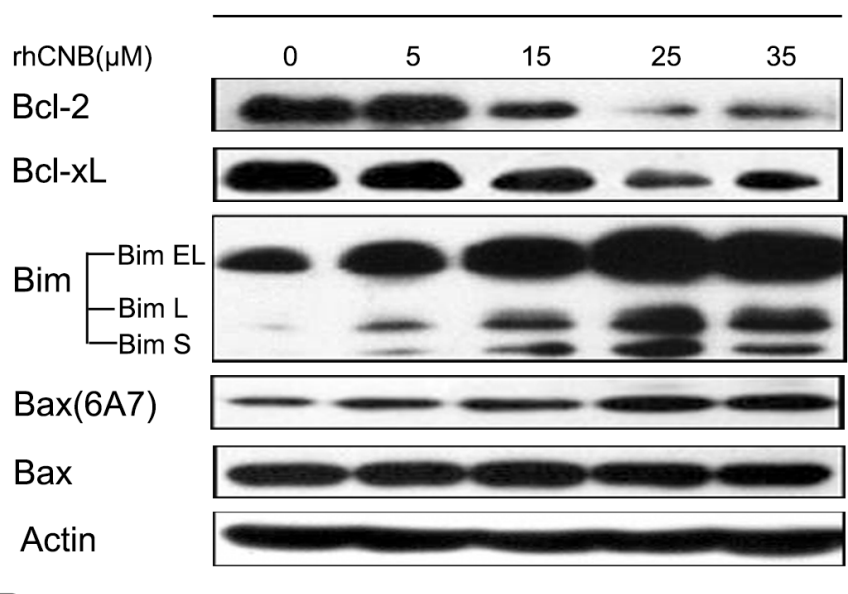

$\mathrm{B}$
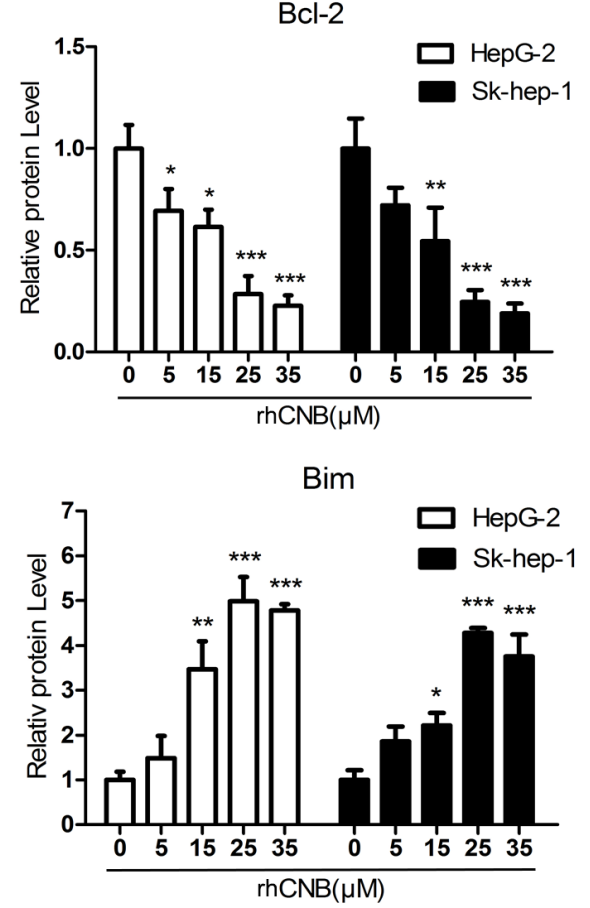

C

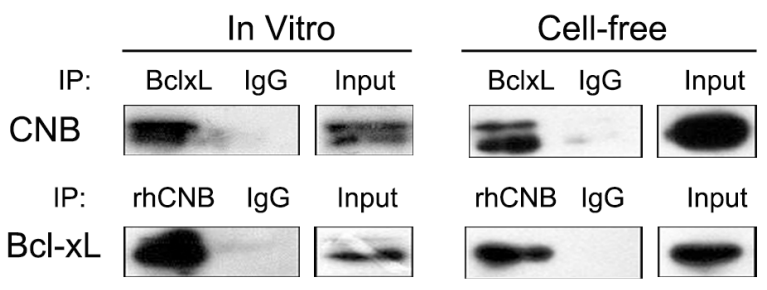

Sk-hep-1

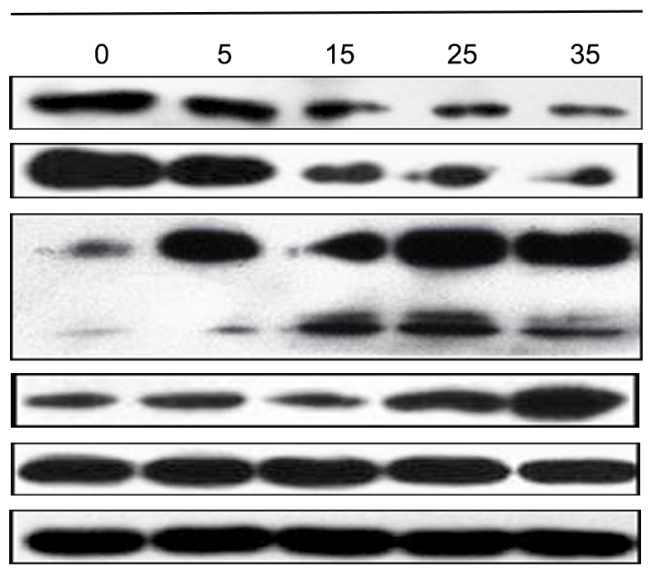

$\mathrm{Bcl}-\mathrm{XL}$
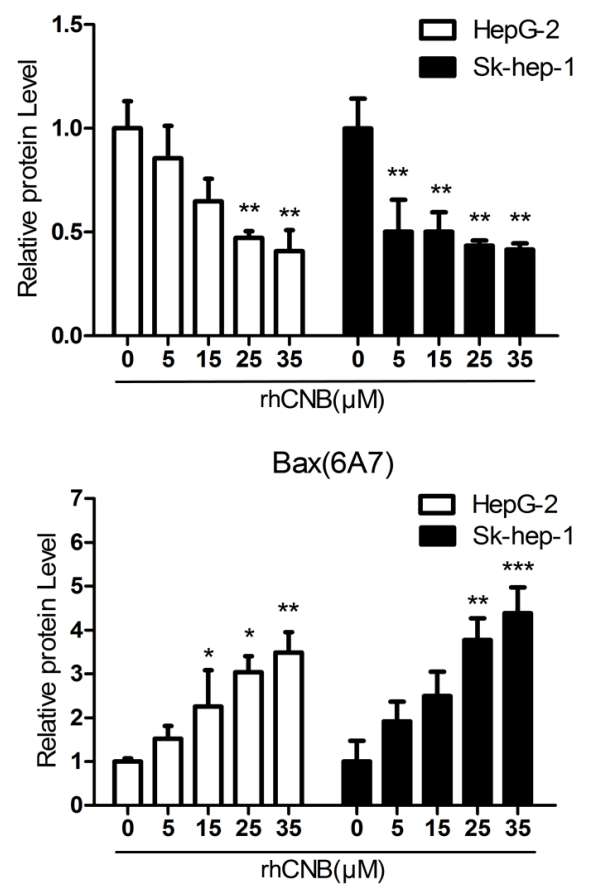

D

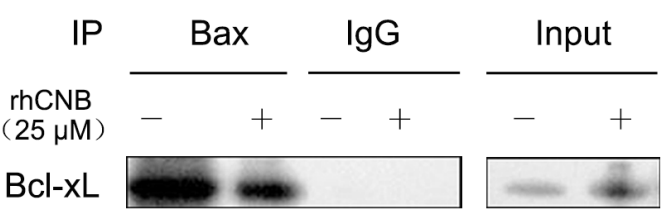

Figure 4: rhCNB alters the expression of Bcl-2 family members and weakens the interaction of Bcl-xL and Bax. (A) HepG-2 cells were exposed to rhCNB for $48 \mathrm{~h}$ after which lysates were prepared and subjected to Western blot analysis using the designated Abs. (B) Densitometry of Bcl-2, Bcl-xL, Bim, Bax(6A7) Western blots (relative to untreated control), in HepG-2 and Sk-hep-1 cells treated with different concentrations of rhCNB for 48h. Values represent mean relative band densities \pm SDs of three independent experiments, $* P<0.05 ; * * P<0.01 ; * * *<0.001$ (compared with control). (C) rhCNB and Bcl-xL interact in vivo and in vitro. HepG-2 cells treated with $15 \mu \mathrm{M}$ rhCNB for $6 \mathrm{~h}$ were lysed and immunoprecipitated with Abs against Bcl-xL and CNB (left panel). Purified recombinant Bcl-xL and rhCNB proteins were incubated for 30 min and immunoprecipitated with Abs against Bcl-xL and CNB (right panel). The immunoprecipitates were separated by SDSPAGE and immunoblotted with CNB and Bcl-xL Abs. (D) HepG-2 cells were treated with $25 \mu \mathrm{M}$ rhCNB for $6 \mathrm{~h}$ after which they were lysed and immunoprecipitated with $\mathrm{Ab}$ against Bax, and the immunoprecipitates were separated by SDS-PAGE and immunoblotted with Bcl-xL Abs. 
in response to $\mathrm{rhCNB}$, and this may promote activation of Bax.

In summary, rhCNB disrupts the stability of mitochondria by altering the expression and functioning of members of the Bcl-2 family, so leading to apoptosis.

\section{Exogenous CNB targets tumors}

Distribution of drugs in vivo is often associated with their pharmacological effects, so we would like to study the distribution of rhCNB in mice, especially at the tumor site. Then in vivo imaging observations were made on tumors formed by HepG-2 cells. We injected fluorescent dye Cy7-labeled rhCNB or free Cy7 into tumor-bearing nude mice by intravenous injection, and observed the distribution of fluorescence in mice at different times. The in vivo imaging results demonstrated that once injected, Cy7 and rhCNB-Cy7 rapidly spread throughout the mice via the bloodstream. Cy7 was quickly discharged via metabolism, after brief retention in the bladder and other metabolic organs, while Cy7-labeled rhCNB was clearly localized in the tumor tissue $6 \mathrm{~h}$ after injection and persisted up to $24 \mathrm{~h}$ (Figure 5A). Ex vivo-fluorescent images and statistical analysis of the excised tumors confirmed the retention of Cy7-labeled rhCNB in the tumor masses (Figure 5B, 5C). These results indicate that rhCNB localizes to tumor masses in vivo, and this longterm localization may contribute to the safety of rhCNB.

\section{DISCUSSION}

Large-scale production of the antitumor candidate drug rhCNB has been initiated. The product is of high purity and stability, and its molecular weight, peptide map, isoelectric point and other indicators demonstrate that it is identical to native CNB $[14,15]$. In order to accelerate the development of rhCNB, we explored the mechanism of its anti-tumor effect in this study. Previous studies have indicated that rhCNB activates the immune system, and thus exerts an anti-tumor effect [13, 16-20]. However, we now provide evidence that it can kill human hepatoma cells directly via a mitochondria dependent way.

We have shown that apoptosis seems to be the primary mechanism of rhCNB-induced cell death, as HepG-2 cells showed obvious morphological damage like nuclei fragmentation, associated with early and late apoptotic events. rhCNB caused depolarization of mitochondria in a dose dependent manner, with a profound cytochrome $\mathrm{C}$ release and cleavage of initiator caspases-9, a characteristic for numerous stimuli that cause apoptosis via the intrinsic pathway involving mitochondria [23-24]. Then, activation of the terminal caspase- 3 , one of the key effector molecules in apoptosis was also observed. These results preliminarily clarify the actions of rhCNB in apoptosis induction.
Since the activity of Bcl-2 family members can be affected or modulated by many antineoplastic therapies [37-40], we examined the contribution of the major members in this family to rhCNB-induced apoptosis. In a variety of tumor cells, $\mathrm{Bcl}-2$ and $\mathrm{Bcl}-\mathrm{xL}$ are highly expressed to evade apoptosis. Studies have shown that up-regulation of BCL-xL increases the chemo-resistance of tumor cells [41-43] and expression of Bcl-2 always correlates with sensitivity to anticancer drugs [44-45]. Inhibition of Bcl-2 and/or Bcl-xL has been shown to induce spontaneous apoptosis of tumor cells [46-48]. In this study, we found that rhCNB treatment resulted in a substantial decrease in expression of Bcl-2 and Bcl-xL in hepatoma cells, while no obvious reduction in normal liver cells (Supplementary Figure 4B). This is explainable as some tumor cells have a higher mitochondrial priming state than normal cells, thus are more sensitive to chemotherapy $[49,50]$. Simultaneously, rhCNB treatment led to an increase in the ratio of $\mathrm{Bax} / \mathrm{Bcl}-2$, characteristic of activation of the mitochondrial apoptotic pathway [47], the active form of Bax did increase; this may have been due at least in part to the down-regulation of Bcl-2 and $\mathrm{Bcl}-\mathrm{xL}$, as they are thought to inhibit the aggregation of Bax on the OMM $[27,46]$. We also detected up-regulation of $\mathrm{Bim}$ in response to rhCNB, an activator protein that inhibit anti-apoptotic Bcl-2 proteins as well as directly activating Bax and Bak [30, 31, 51], with Bax preference [52]. Once activated, Bax forms channels in the OMM, leading to mitochondrial outermembrane permeabilization (MOMP) to initiate mitochondrial apoptosis [23, 24]. As stated before, our data support this mechanism for the effect of rhCNB. Thus we hypothesize that $\mathrm{rhCNB}$ reduces the expression of Bcl-2 and Bcl-xL so allowing Bax to accumulate in the OMM, and they also upregulate Bim to further activate Bax, which then triggers the mitochondria apoptosis pathway.

We showed that rhCNB becomes located in mitochondria once it enters hepatoma cells. Mitochondria play an important role in cell metabolism, apoptosis, calcium regulation and other physiological activities [53], and the presence of rhCNB may affect their function. Our results show that rhCNB binds to the mitochondrial outer membrane protein Bcl-xL in vitro and in cell-free system. This may disrupt the interaction of $\mathrm{Bcl}-\mathrm{xL}$ and Bax, interfering with inhibition of Bax by Bcl-xL and leading cells to be more sensitive to apoptosis. It seems that rhCNB can also enter the inner mitochondria space, but the role it plays there is unknown. It has been shown to bind to isolated mitochondria in a $\mathrm{Ca}^{2+}$-dependent manner [19] and cause endoplasmic reticulum stress (unpublished data). As a result, when it enters mitochondria, it will presumably cause mitochondrial calcium overload and influence the opening of the mitochondrial permeability transition pore (PTP) [54]. Future studies of the role of $\mathrm{Ca}^{2+}$ in rhCNB-induced apoptosis should lead to a better understanding of the direct killing mechanism of rhCNB. 
As a newly reported candidate drug for tumor treatment, rhCNB not only has the excellent ability of tumor suppression, but also has the property of low toxicity in vitro and in vivo. Previous acute toxicity experiments indicated that mice can endure at least 50 fold the physiological dose of rhCNB [12]. LD50 of acute toxicity test on cynomolgus monkey is $1600 \mathrm{mg} / \mathrm{kg}, 300$ fold of the normal dose. Long-term toxic experiment showed that rhCNB has no significant toxicity on immune organs and other vital organs of rats and cynomolgus monkeys (completed by a qualified center for drug safety evaluation and research). In this study, we confirmed it again in LO2 cells (Figure 1B) and mouse primary hepatocytes (Supplementary Figure 4A). We also showed that rhCNB can persist in the tumor masses of nude mice for as long as 24 hours, which may contribute to the safety of rhCNB in vivo. This is another significant advantage of rhCNB as the utility of many antitumor drugs was limited by lack of specificity, and researchers have conjugated some drugs with carriers to target their delivery [55-57].

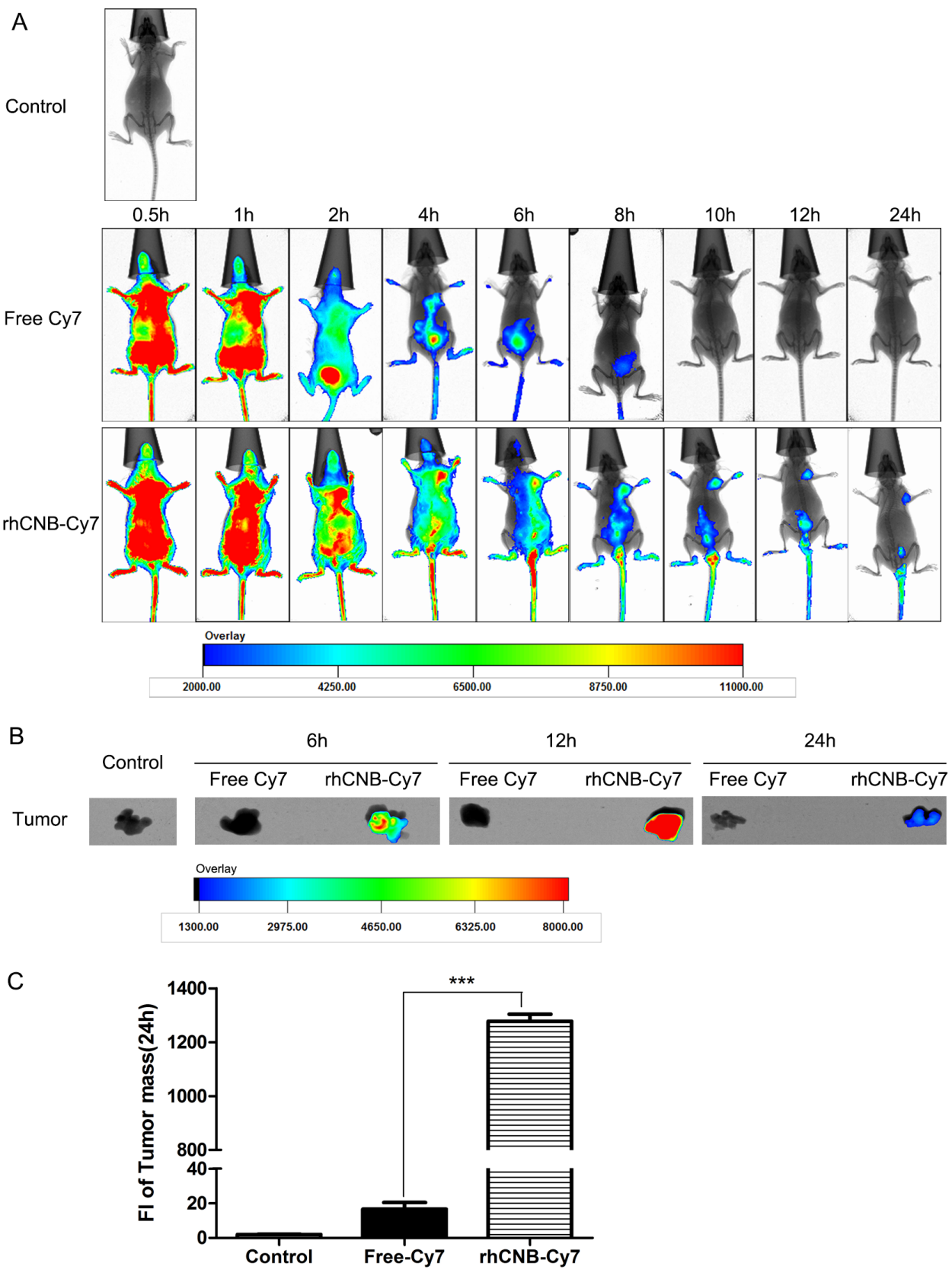

Figure 5: rhCNB localizes to tumors in vivo. (A) In vivo real-time imaging of the tumors arising from HepG-2 cells in nude mice after intravenous injection of free Cy7 or rhCNB-Cy7. (B) Ex vivo optical images of HepG-2 tumor masses from mice at $6 \mathrm{~h}, 12 \mathrm{~h}$, and $24 \mathrm{~h}$. Note: Cy7 refers to cyanine 7, which is used as a fluorescent probe. (C) Quantitative analysis of fluorescence intensity in tumor masses. Bar diagram represents the mean fluorescence intensity $\pm \mathrm{SDs}, * * * \mathrm{P}<0.001$. 
In addition, it could be useful to explore which parts of the rhCNB structure lead to its tumor-targeting. RhCNB might also be conjugated with other drugs to enhance their antitumor effect and reduce side effect.

We have reported for the first time that rhCNB can activate the mitochondrial apoptosis pathway by modulating the expression and activity of members of the Bcl-2 family, and induce apoptosis in human hepatoma cells. It also appears to be specifically taken up by HepG-2 solid tumors. Our findings have deepened our understanding of the anti-tumor mechanism of rhCNB and provided guidance for its development and application.

\section{MATERIALS AND METHODS}

\section{Materials}

Recombinant human CNB [EU <0.25U] was provided by Haikou Qili Pharmaceutical Co., Ltd. The anti-caspase-3(8G10), anti-cleaved caspase-3(Asp175), anti-caspase-9(9502), cytochrome C (136F3), Bcl2(50E3), Bcl-xL(54H6) and $\mathrm{Bim}(\mathrm{C} 34 \mathrm{C} 5)$ antibodies were purchased from Cell Signaling Technology; the anti$\operatorname{Bax}(610982)$ and anti-Bax(6A7)(556467) antibodies were purchased from BD Biosciences; the anti-CNB antibody was prepared by our laboratory [58]. The Ni-NTA columns were from Nano-Micro Co, Ltd. (C05W206E). The following reagents were also used: lipofectamine 2000 (Life Technologies; 11668-019), a caspase-3/7 Live Cell Fluorometric Assay Kit (KeyGEN BioTECH; KGAS03750), and Сy7 (Fanbo Biochemicals; 943298-08-6).

\section{Cells and cell culture}

The following cells lines were used: HepG-2, Skhep-1 (ATCC), LO2(kindly donated by Professor Zhou Gangqiao, Academy of Military Medical Sciences), DsRed2/HistoneH2B-EGFP labeled HepG-2 cell (AntiCancer Biotech (Beijing)). LO2 were cultured in DMEM (Gibco; C11965500BT), other cell lines were cultured in MEM (Gibco; C11095500BT), containing 10\% fetal bovine serum (Gibco; 10099-141). All cells were maintained at $37^{\circ} \mathrm{C}$ in a humidified incubator with $5 \%$ $\mathrm{CO}_{2}$.

\section{CCK-8 assay}

Briefly, $8 \times 10^{3}$ of HepG- 2 cells or $1 \times 10^{4}$ LO 2 cells were seeded in wells of a 96 -well plate, with medium as a blank-control. After $24 \mathrm{~h}$ incubation, cells were exposed to increasing concentrations of CNB $(0-35 \mu \mathrm{M})$ for an additional $48 \mathrm{~h}$. Then added $10 \mu \mathrm{L}$ of CCK8 working solution per well (including Blank) for 1.5-2h incubation in the dark, and measured the absorbance at 450nm. The relative cell viability (\%) was calculated as the following formula: [A (drug treated group) -A (blank)] / [A (untreated group) -A (blank)] $\times 100$ (wherein A represents absorbance at $450 \mathrm{~nm}$ ). There was a minimum of four sets of reaction per group, and the results are presented as bar diagrams along with standard deviations (SDs).

\section{Caspase- $3 / 7$ activity}

The activation of caspase-3/7 was quantified with a Caspase-3/7 Live Cell Fluorometric Assay Kit (KeyGEN BioTECH; KGAS037-50) in accordance with the manufacturer's protocol. Cells were seeded in 12well microtiter plates and treated with $0-35 \mu \mathrm{M}$ rhCNB for $48 \mathrm{~h}$, followed by substrate in Caspase 3/7 assay buffer for $45 \mathrm{~min}$. Caspase-3/7 activities were calculated from the fluorescence measured in a Multi-Microplate Reader( BMG LABTECH).

\section{Analysis of apoptosis by flow cytometry}

The percentage of cells undergoing apoptosis after treatment with rhCNB was determined using an Annexin V-FITC Apoptosis Detection Kit I (BD Bioscience; 556547). The kit uses FITC-conjugated Annexin-V to detect phosphatidylserine (PS) on the external membrane of apoptotic cells, and PI (propidium iodide) as a dead cells marker. HepG- 2 cells $\left(4 \times 10^{5}\right)$ were seeded in wells of a 6-well plate and incubated for $24 \mathrm{~h}$. Following rhCNB treatment (0-35 $\mu \mathrm{M}, 48 \mathrm{~h})$, cells were harvested, washed with ice cold PBS and incubated with Annexin V-FITC and PI for $15 \mathrm{~min}$ at room temperature in the dark, and analyzed by flow cytometry.

\section{Measurement of mitochondrial transmembrane potential by flow cytometry}

Mitochondrial membrane potential $(\Delta \Psi \mathrm{m})$ was measured with a JC-1 Apoptosis Detection Kit (KeyGEN BioTECH; KGA601). Briefly, $4 \times 10^{5}$ HepG-2 cells and $2.5 \times 10^{5}$ Sk-hep-1 cells were seeded in wells of a 6 -well plate and incubated for $24 \mathrm{~h}$. Following rhCNB treatment (0-35 $\mu \mathrm{M}, 24 \mathrm{~h})$, they were harvested, washed with icecold PBS and incubated with JC-1 dye for 20 min at $37^{\circ} \mathrm{C}$ in the dark. Cells were washed and samples were analyzed by flow cytometer after applying appropriate gates. The mean intensities of red and green fluorescence were recorded, and the ratio was considered the transmembrane potential $(\Delta \psi \mathrm{M})$.

\section{CNB-GFP fusion protein}

CNB cDNA and a sequence coding for a linker (GGGSGGGS) were inserted into pet25b (+) to construct a recombinant plasmid carrying a GFP tag. The plasmid was transformed into E. coli BL21 (DE3), and the cells were induced with $1 \mathrm{mM}$ IPTG (C9H18N5S, Merck) to initiate expression of the fusion protein. The cells were harvested and sonicated, and the protein was purified with 
Ni-NTA resin (C05W206E, Nano-Micro) and analyzed by SDS-PAGE.

\section{Co-localization analysis using confocal laser scanning microscopy}

Confocal microscopy was performed with a Zeiss LSM700 laser scanning confocal microscope. HepG-2 or SK-hep-1 cells were seeded in $35-\mathrm{mm}$ glass-bottom dishes (In Vitro Scientific; D35-20-1-N) and transfected with the indicated plasmids for $48 \mathrm{~h}$. $5 \mu \mathrm{M}$ CNB-GFP was then added to the cells and incubated for $30 \mathrm{~min}$, followed by three washes with PBS. The distribution of fluorescence was determined.

\section{Western blotting and co-immunoprecipitation}

For Western blotting, approximately $1 \times 10^{6} \mathrm{HepG}-2$ or SK-HEP-1 cells were lysed with RIPA buffer. Clarified lysates were separated by SDS-PAGE, transferred to polyvinylidene fluoride membranes and incubated with the indicated antibodies ( $1.5 \mathrm{~h}$ at room temperature or overnight at $4{ }^{\circ} \mathrm{C}$ ). Proteins of interest were detected with secondary antibodies conjugated to HRP and Enlight ${ }^{\mathrm{TM}}$ Western Blot Detection Reagents (Engreen Biosystem; 29100). Pre-stained protein molecular weight markers (Thermo Scinentific; 26617) were included in each gel. To confirm equal loading of proteins in the gels, the blots were also probed with an antibody against $\beta$-actin (Applygen Technologies; C1313). For co-immunoprecipitation, $1 \times 10^{7}$ HepG-2 cells were treated with rhCNB for $4 \mathrm{~h}$. Cells were lysed in ice-cold lysis buffer containing $1 \%$ NP-40, $50 \mathrm{mM}$ Tris- $\mathrm{HCl}(\mathrm{pH} 8.0), 150 \mathrm{mM} \mathrm{NaCl}$ and protease inhibitors (Roche; 4693116001) for $30 \mathrm{~min}$. After centrifugation at $13,000 \mathrm{~g}$ for $30 \mathrm{~min}$ at $4{ }^{\circ} \mathrm{C}$, lysates were pre-cleared by incubating $\left(4^{\circ} \mathrm{C}, 2 \mathrm{~h}\right)$ with $30 \mu \mathrm{L}$ protein A/G Sepharose beads (GE Healthcare; 17-127901/17-0618-01). The precleared lysates were incubated overnight with $2-5 \mu \mathrm{g}$ of the indicated antibodies, and immunocomplexes were captured with $40 \mu \mathrm{L}$ protein $\mathrm{A} / \mathrm{G}$ Sepharose beads. The presence of given proteins in these complexes was determined by Western blot analysis. Most primary antibodies were diluted to 1: 1000, while anti-cleaved caspase-3, anti-cleaved caspase- 9 and antiBax(6A7) antibodies were diluted to 1:500. All secondary antibodies were diluted to 1: 5000 .

\section{Detection of mitochondrial rhCNB}

Mitochondrial and cytosolic fractions of HepG-2 or Sk-hep-1 cells incubated with rhCNB for the indicated times were prepared using a Cell Mitochondria Isolation Kit (Beyotime; C3601). The presence of rhCNB in mitochondria was determined by Western blotting. To test whether rhCNB enters the inner space of mitochondria, mitochondria were digested with digestion buffer $(20 \mathrm{mM}$ HEPES-KoH (PH7.4), 80 mM KOAc, 5 mM MgOAc, 250 $\mathrm{mM}$ sucrose and $20 \mu \mathrm{M}$ Proteinase K (Amresco; 0706)) on ice for $30 \mathrm{~min}$ and analyzed by Western blotting.

\section{Analysis of Cyto-C distribution by Western blotting}

Mitochondrial and cytosolic fractions of HepG2 cells incubated with rhCNB for the indicated times were prepared with a Cell Mitochondria Isolation Kit (Beyotime; C3601). The distribution of rhCNB was determined by Western blotting. VDAC1 was used as a mitochondrial protein reference, and actin as a cytoplasmic protein reference.

\section{In vivo imaging of rhCNB in HepG-2 tumors}

Six-week-old female BALB/c nude mice were from Beijing Vital River Laboratory Animal Technology. All animal experimental procedures were conducted according to protocols approved by Ethic and Animal Welfare Committee (NO.CLS-EAW-2013-015) and were conducted in strict accordance with institutional guidelines. For tumor implantation, a total of $2 \times 10^{6}$ HepG-2 cells were injected subcutaneously into the right flank of the mice. After the tumors reached approximately $800 \mathrm{~mm}^{3}$, the mice received free Cy7 or Cy7- labeled rhCNBvia the tail vein, and were scanned 0.5, 1, 2, 4, 6, $8,10,12$ and $24 \mathrm{~h}$ later using a Kodak multimode imaging system (Carestream Health, Inc., USA). Mice were killed at $6,12,24 \mathrm{~h}$, and the tumor masses were excised for detection of fluorescence signal intensity.

\section{Statistical analysis}

Data are expressed as means \pm SDs. Statistical analysis was performed by one way ANOVA and Student's t-test using SPSS 13.0 software. Values were considered significant at $P \leq 0.05$.

\section{Author contributions}

Y.Y. and H.Y. performed the data analysis and wrote the manuscript. Q.W. revised the manuscript. Q.W. and B.X. contributed to the study design. J.Y. and L.L. participated in the study. All authors reviewed the manuscript and discussed the project at all stages.

\section{ACKNOWLEDGMENTS}

This research was funded by the National Natural Science Foundation of China, The National Important Basic Research Project and the National Important Novel Medicine Research Project. 


\section{CONFLICTS OF INTEREST}

The authors declare no competing interests.

\section{REFERENCES}

1. Klee CB, Crouch TH, Krinks MH. Calcineurin: a calciumand calmodulin-binding protein of the nervous system. Proc Natl Acad Sci USA. 1979; 76:6270-3.

2. Klee CB, Ren H, Wang X. Regulation of the calmodulinstimulated protein phosphatase, calcineurin. J Biol Chem. 1998; 273:13367-70.

3. Clipstone NA, Crabtree GR. Identification of calcineurin as a key signalling enzyme in T-lymphocyte activation. Nature. 1992; 357:695-7.

4. Yu DY, Luo J, Bu F, Zhang W, Wei Q. Effects of cyclosporin A. FK506 and rapamycin on calcineurin phosphatase activity in mouse brain. IUBMB Life. 2006; 58:429-33.

5. Jayanthi S, Deng X, Ladenheim B, McCoy MT, Cluster A, Cai NS, Cadet JL. Calcineurin/NFAT-induced up-regulation of the Fas ligand/Fas death pathway is involved in methamphetamine-induced neuronal apoptosis. Proc Natl Acad Sci USA. 2005; 102:868-73.

6. Wu X, Nguyen BC, Dziunycz P, Chang S, Brooks Y, Lefort K, Hofbauer GF, Dotto GP. Opposing roles for calcineurin and ATF3 in squamous skin cancer. Nature. 2010; 465:368-72.

7. Rusnak F, Mertz P. Calcineurin: form and function. Physiol Rev. 2000; 80:1483-521.

8. Feng B, Stemmer PM. Interactions of calcineurin A, calcineurin B, and $\mathrm{Ca}^{2+}$. Biochemistry. 1999; 38:12481-9.

9. Yang SA, Klee CB. Low affinity $\mathrm{Ca}^{2+}$-binding sites of calcineurin B mediate conformational changes in calcineurin A. Biochemistry. 2000; 39:16147-54.

10. Li W, Handschumacher RE. Identification of two calcineurin B-binding proteins: tubulin and heat shock protein 60. Biochim Biophys Acta. 2002; 1599:72-81.

11. Li N, Zhang Z, Zhang W, Wei Q. Calcineurin B subunit interacts with proteasome subunit alpha type 7 and represses hypoxiainducible factor- $1 \alpha$ activity via the proteasome pathway. Biochem Biophys Res Commun. 2011; 405:468-72.

12. Wei Q, Lian ML, Jing FZ, Zhang N, Yan MS, Chen Y, Gao QS. Studies of calcineurin B subunit from genetic engineering for use in medicine. Drug Dev Res. 2002; 56:40-3.

13. Su Z, Yang R, Zhang W, Xu L, Zhong Y, Yin Y, Cen J, DeWitt JP, Wei Q. The synergistic interaction between the calcineurin B subunit and IFN- $\gamma$ enhances macrophage antitumor activity. Cell Death Dis. 2015; 6:1-13.

14. Wei Q, Yan MS, Gao QS, Jiang GH, Lian ML, Chen Y. Pharmaceutical composition containing calcineurin B subunit. PRC Patent. ZL 981 17642.9. 2003-02-05.
15. Wei Q, Yan MS, Gao QS, Jiang GH, Lian ML, Chen Y. Pharmaceutical composition containing calcineurin B subunit. US Patent. 7,026,118 B1. 2006-04-11.

16. Li J, Guo JX, Su ZY, Hu ML, Liu W, Wei Q. Calcineurin subunit B activates dendritic cells and acts as a cancer vaccine adjuvant. Int Immunol. 2011; 23:327-34.

17. Liu L, Su Z, Xin S, Cheng J, Li J, Xu L, Wei Q. The calcineurin $B$ subunit $(\mathrm{CNB})$ is a new ligand of integrin $\alpha \mathrm{M}$ that mediates CnB-induced Apo2L/TRAIL expression in macrophages. Immunol. 2012; 188:238-47.

18. Su Z, Xin S, Xu L, Cheng J, Guo J, Li L, Wei Q. The calcineurinB subunit induces TNF-related apoptosisinducing ligand (TRAIL) expression via CD11b-NF-кB pathway in RAW264.7 macrophages. Biochem Biophys Res Commun. 2012; 417:777-83.

19. Cheng J, Tang W, Su Z, Guo J, Tong L, Wei Q. Calcineurin subunit B promotes TNF-alpha-induced apoptosis by binding to mitochondria and causing mitochondrial $\mathrm{Ca}^{2+}$ overload. Cancer Lett. 2012; 321:169-78.

20. Yang J, Qin N, Zhang H, Yang R, Xiang B, Wei Q. Cellular uptake of exogenous calcineurin B is dependent on TLR4/ $\mathrm{MD} 2 / \mathrm{CD} 14$ complexes, and $\mathrm{CnB}$ is an endogenous ligand of TLR4. Sci Rep. 2016; 6:24346.

21. Nagata S. Apoptosis by death factor. Cell. 1997; 88:355-65.

22. Wallach D, Kang TB, Kovalenko A. The extrinsic cell death pathway and the élan mortel. Cell Death Differ. 2008; 15:1533-41.

23. Vaux DL. Apoptogenic factors released from mitochondria. Biochim Biophys Acta. 2011; 1813:546-50.

24. Wang X. The expanding role of mitochondria in apoptosis. Genes Dev. 2001; 15:2922-33.

25. Martinou JC, Youle RJ. Mitochondria in apoptosis:Bcl-2 family members and mitochondrial dynamics. Dev Cell. 2011; 21:92-101.

26. $\mathrm{Ku} \mathrm{B}$, Liang $\mathrm{C}$, Jung JU, Oh BH. Evidence that inhibition of Bax activation by Bcl-2 involves its tight and preferential interaction with the BH3 domain of Bax. Cell Res. 2011; 21:627-41.

27. Edlich F, Banerjee S, Suzuki M, Cleland MM, Arnoult D, Wang C, Neutzner A, Tiandra N, Youle RJ. Bcl-x(L) retrotranslocates $\mathrm{Bax}$ from the mitochondria into the cytosol. Cell. 2011; 145:104-16.

28. Chen L, Willis SN, Wei A, Smith BJ, Fletcher JI, Hinds MG, Colman PM, Day CL, Adams JM, Huang DC. Differential targeting of pro-survival Bcl-2 proteins by their BH3-only ligands allows complementary apoptotic function. Mol Cell. 2005; 17:393-403.

29. Willis SN, Fletcher JI, Kaufmann T, van Delft MF, Chen L, Czabotar PE, Ierino H, Lee EF, Fairlie WD, Bouillet P, Strasser A, Kluck RM, Adams JM, Huang DC. Apoptosis initiated when $\mathrm{BH} 3$ ligands engage multiple Bcl-2 homologs, not Bax or Bak. Science. 2007; 315:856-9. 
30. Czabotar PE, Westphal D, Dewson G, Ma S, Hockings C, Fairlie WD, Lee EF, Yao S, Robin AY, Smith BJ, Huang DC, Kluck RM, Adams JM, Colman PM. Bax crystal structures reveal how $\mathrm{BH} 3$ domains activate $\mathrm{Bax}$ and nucleate its oligomerization to induce apoptosis. Cell. 2013; 152:519-31.

31. Leshchiner ES, Braun CR, Bird GH, Walensky LD. Direct activation of full-length proapoptotic Bak. Proc Natl Acad Sci U S A. 2013; 110:986-95.

32. Eskes R, Desagher S, Antonsson B, Martinou JC. Bid induces the oligomerization and insertion of Bax into the outer mitochondrial membrane. Mol Cell Biol. 2000; 20:929-35.

33. Certo M, Del GM, Nishino M, Wei G, Korsmeyer S, Armstrong SA, Letai A. Mitochondria primed by death signals determine cellular addiction to antiapoptotic Bcl-2 family members. Cancer Cell. 2006; 9:351-65.

34. Chipuk JE, Fisher J, Dillon CP, Kriwacki RW, Kuwana T, Green DR. Mechanism of apoptosis induction by inhibition of the antiapoptotic Bcl-2 proteins. Proc Natl Acad Sci U S A. 2008; 105:20327-332.

35. O'Connor L, Strasser A, O'Reilly LA, Hausmann G, Adams JM, Cory S, Huang DC. Bim: a novel member of the Bcl-2 family that promotes apoptosis. EMBO J. 1998; 17:384-95.

36. Danial NN, Korsmeyer SJ. Cell death: critical control points. Cell. 2004; 116:205-19.

37. Rahmani M, Aust MM, Attkisson E, Williams DC Jr, Ferreira-Gonzalez A, Grant S. Inhibition of Bcl-2 antiapoptotic members by obatoclax potently enhances sorafenib-induced apoptosis in human myeloid leukemia cells through a Bim-dependent process. Blood. 2012; 119:6089-98.

38. Pan R, Hogdal LJ, Benito JM, Bucci D, Han L, Borthakur G, Cortes J, DeAngelo DJ, Debose L, Mu H, Döhner H, Gaidzik VI, Galinsky I, et al. Selective Bcl-2 inhibition by ABT-199 causes on-target cell death in acute myeloid leukemia. Cancer Discov. 2014; 4:362-75.

39. Hilgendorf KI, Leshchiner ES, Nedelcu S, Maynard MA, Calo E, Ianari A, Walensky LD, Lees JA. The retinoblastoma protein induces apoptosis directly at the mitochondria. Genes Dev. 2013; 27:1003-15.

40. Saleh AM, El-Abadelah MM, Aziz MA, Taha MO, Nasr A, Rizvi SA. Antiproliferative activity of the isoindigo 5'-Br in HL-60 cells is mediated by apoptosis, dysregulation of mitochondrial functions and arresting cell cycle at G0/G1 phase. Cancer Lett. 2015; 361:251-61.

41. Wong M, Tan N, Zha J, Peale FV, Yue P, Fairbrother WJ, Belmont LD. Navitoclax (ABT-263) reduces Bcl-xLmediated chemoresistance in ovarian cancer models. Mol Cancer Ther. 2012; 11:1026-35.

42. Heere-Ress E, Thallinger C, Lucas T, Schlagbauer-Wadl H, Wacheck V, Monia BP, Wolff K, Pehamberger H, Jansen B. Bcl-XL is a chemoresistance factor inhuman melanoma cells that can be inhibited by antisense therapy. Int J Cancer. 2002; 99:29-34.
43. Wei G, Margolin AA, Haery L, Brown E, Cucolo L, Julian B, Shehata S, Kung AL, Beroukhim R, Golub TR. Chemical genomics idenfies small-molecule MCL1 repressors and BCL-xL as a predictor of MCL1 dependency. Cancer Cell. 2012; 21:547-62.

44. Anderson MA, Deng J, Seymour JF, Tam C, Kim SY, Fein J, Yu L, Brown JR, Westerman D, Si EG, Majewski IJ, Segal D, Heitner Enschede SL, et al. The BCL2 selective inhibitor venetoclax induces rapid onset apoptosis of CLL cells in patients via a TP53-independent mechanism. Blood. 2016; 127:3215-24.

45. Reed J C. Promise and problems of Bcl-2 antisense therapy. J Natl Cancer Inst. 1997; 89:988-90.

46. Chipuk JE, Moldoveanu T, Llambi F, Parsons MJ, Green DR. The Bcl-2 family reunion. Mol Cell. 2010; 37:299-310.

47. Czabotar PE, Lessene G, Strasser A, Adams JM. Control of apoptosis by the BCL2 protein family: implications for physiology and therapy. Nat Rev Mol Cell Biol. 2014; 15:49-63.

48. Rahmani M, Aust MM, Attkisson E, Williams DC Jr, Ferreira-Gonzalez A, Grant S. Dual Inhibition of Bcl-2 and Bcl-xL strikingly enhances PI3K inhibition-induced apoptosis in human myeloid leukemia cells through a GSK3- and Bim-dependent mechanism. Cancer Res. 2013; 73:1340-51.

49. Vo TT, Ryan J, Carrasco R, Neuberg D, Rossi DJ, Stone RM, Deangelo DJ, Frattini MG, Letai A. Relative mitochondrial priming of myeloblasts and normal HSCs determines chemotherapeutic success in AML. Cell. 2012; 151:344-55.

50. Liu JC, Guan X, Ryan JA, Rivera AG, Mock C, Agrawal V, Letai A, Lerou PH, Lahav G. High mitochondrial priming sensitizes hESCs to DNA-damage-induced apoptosis. Cell Stem Cell. 2013; 13:483-91.

51. Lovell JF, Billen LP, Bindner S, Shamas-Din A, Fradin C, Leber B, Andrews DW. Membrane binding by tBid initiates an ordered series of events culminating in membrane permeabilization by Bax. Cell. 2008; 135:1074-84.

52. Sarosiek KA, Chi X, Bachman JA, Sims JJ, Montero J, Patel L, Flanagan A, Andrews DW, Sorger P, Letai A. Bid preferentially activates Bak while Bim preferentially activates Bax, affecting chemotherapy response. Mol Cell. 2013; 51:751-65.

53. Song IS, Kim HK, Jeong SH, Lee SR, Kim N, Rhee BD, Ko $\mathrm{KS}$, Han J. Mitochondrial peroxiredoxin III is a potential target for cancer therapy. Int J Mol Sci. 2011; 12:7163-85.

54. Siemen D, Ziemer $M$. What is the nature of the mitochondrial permeability transition pore and what is it not? IUBMB Life. 2013; 65:255-62.

55. Zhang L, Yao HJ, Yu Y, Zhang Y, Li RJ, Ju RJ, Wang XX, Sun MG, Shi JF, Lu WL. Mitochondrial targeting liposomes incorporating daunorubicin and quinacrine for treatment of relapsed breast cancer arising from cancer stem cells. Biomaterials. 2012; 33:565-82. 
56. Qian X, Peng XH, Ansari DO, Yin-Goen Q, Chen GZ, Shin $\mathrm{DM}$, Yang L, Young AN, Wang MD, Nie S. In vivo tumor targeting and spectroscopic detection with surface-enhanced Raman nanoparticle tags. Nat Biotechnol. 2008; 26:83-90.

57. Lin K, Rubinfeld B, Zhang C, Firestein R, Harstad E, Roth L, Tsai SP, Schutten M, Xu K, Hristopoulos M, Polakis P. Preclinical development of an anti-NaPi2b (SLC34A2) antibody-drug conjugate as a therapeutic for non-small cell lung and ovarian cancers. Clin Cancer Res. 2015; 21:5139-50.

58. Yang CG, Wei Q. An immunization method for the preparation of antibodies. PRC Patent. ZL 20061 0165776.4. 2010 . 